\title{
Suggestions for diatom-based monitoring in intermittent streams
}

\author{
Elisa Falasco*, Elena Piano and Francesca Bona \\ Department of Life Sciences and Systems Biology, University of Turin, via Accademia Albertina 13, 10123 Turin, Italy
}

\begin{abstract}
Over the last decades, river lentification processes and droughts have been dramatically spreading worldwide, due to global and local drastic changes due to human activities. Under this scenario, the evaluation of physical disturbance caused by intermittency and droughts has become more and more relevant. In this research, we compare samples collected in Mediterranean streams following both traditional and experimental approaches with the aim of understanding if diatom indices calculated from a new sampling strategy could provide additional information for the physical disturbance assessment. Moreover, we also evaluated the response of functional metrics. Our results demonstrated that even though an enhanced sampling method better reflects hydrological disturbance than the traditional one, diatom indices do not detect it. Conversely, functional traits proved to be important metrics for the hydrological disturbance assessment. In particular, benthic diatom chlorophyll $a$ showed significantly lower values in sections more subject to droughts. With respect to ecological guilds, the motile taxa proved to be linked to depositional areas, which resulted important microhabitats (MHs) to be explored in rivers affected by lentification. Including different $\mathrm{MHs}$ in the sampling process improves the information we can obtain from the analysis of the diatom community and presents important implications in documenting species distribution and autecology.
\end{abstract}

Keywords: diatom indices / functional metrics / hydrological disturbance / intermittency / Mediterranean streams

Résumé - Suggestions pour la biosurveillance avec les diatomées benthiques dans les rivières intermittentes. Au cours des dernières décennies, les processus de ralentissement des rivières et les sécheresses ont été considérablement répandus dans le monde entier, en raison de changements drastiques globaux et locaux dûs aux activités humaines. Selon ce scénario, l'évaluation des perturbations physiques causées par intermittence et les sécheresses est devenue de plus en plus pertinente. Dans cette recherche, nous comparons les échantillons prélevés dans des rivières méditerranéennes suivant des approches traditionnelles et expérimentales dans le but de comprendre si les indices diatomées calculés à partir d'une nouvelle stratégie d'échantillonnage pourraient fournir des informations supplémentaires pour l'évaluation des perturbations physiques. De plus, nous avons également évalué la réponse des paramètres fonctionnels. Nos résultats ont montré que, même si une méthode d'échantillonnage améliorée reflète mieux les perturbations hydrologiques que la méthode traditionnelle, les indices diatomées ne les détectent pas. À l'inverse, les traits fonctionnels se sont avérés être des paramètres importants pour l'évaluation des perturbations hydrologiques. En particulier, la chlorophylle a des diatomées benthiques a montré des valeurs significativement plus faibles dans les sections plus exposées à la sécheresse. En ce qui concerne les guildes écologiques, les taxons motiles se sont avérés être liés à des zones de dépôt, qui sont des microhabitats importants à explorer dans les rivières touchées par le ralentissement. Inclure différents microhabitats dans le processus d'échantillonnage améliore les informations que nous pouvons obtenir de l'analyse de la communauté de diatomées et présente des implications importantes dans la connaissance de la répartition et de l'autécologie des espèces.

Mots clés : indice diatomées / paramètres fonctionnels / perturbations hydrologiques / intermittence / cours d'eau méditerranéens

\footnotetext{
* Corresponding author: elisa.falasco@unito.it
} 


\section{Introduction}

Diatom-based indices have been routinely used in monitoring programs for the water quality assessment since their inclusion in the WFD 2000/60. In general, European countries follow standard methods for diatom sampling (Kelly et al., 1998; European Committee for Standardization, 2003). According to the main European standard guidelines, riffles are the preferred zone for sample selection, while very slow current areas should be avoided. Despite this, it has been already demonstrated that in some rivers there is a significant variation in periphyton biomass among stream microhabitats (MHs), mainly due to differences in photosynthetically active radiation and grazing pressure (Fisher and Dunbar, 2007). This patchiness can be also typical of the Mediterranean intermittent rivers, which are naturally characterized by the alternation of hydrological stability (HS) and instability periods. Indeed, during summer, some stretches experience strong flow variations, from very reduced but persistent water presence, to the complete dryness of the riverbed (Gordon et al., 1992).

The consequences of this phenomenon on the aquatic ecosystems have been explored in recent publications. As long as the physical environment is considered, water flow reduction (i.e. "lentification") interrupts the connections between the riparian vegetation and the stream ecosystem. The loss of connectivity causes alterations in the transport and processing of organic material and nutrients, with consequences on the biogeochemical cycles both at reach and basin scales (Boix et al., 2010; Tornés and Ruhí, 2013; Acuña et al., 2015). Lentification alters macrohabitat availability from a riffle-pool sequence toward the creation of isolated pools (Bonada et al., 2006), leading to the increase of habitat fragmentation. On the last decades, the lentification processes and droughts have been spreading in even larger areas even outside the Mediterranean region (Fenoglio et al., 2007; Elias et al., 2015). This phenomenon is mainly due to the uncontrolled water exploitation caused by the increasing human needs (Tockner and Stanford, 2002). Moreover, on the basis of most climate change models, these scenarios are expected to increase both in frequency and in intensity. Mediterranean hydroecoregions are recognized as the main "hot spots" for water availability changes (Barceló and Sabater, 2010), but droughts and water scarcity will soon impact areas so far unaffected by these events.

Severe repercussions are also expected on riverine biotic communities (Lake, 2000; Fenoglio et al., 2010). Indeed, lentification and fragmentation of freshwater habitats have consequences on the metabolism of the biotic communities and, in particular, of the primary producers. Dry periods have immediate effects on authotrophic organisms promoting heterotrophy in biofilms (Acuña et al.,2015) and causing high mortality rates within few days (i.e. from 70 to $80 \%$ of dead diatoms during the first days of exposure; Barthès et al., 2014).

Collecting diatoms from different MHs within the same stretch would greatly improve the sample representativeness (Fisher and Dunbar, 2007). Multi-habitat sampling would provide a better representation of the site conditions and integrate the information missed in a single standard sampling (Smucker and Vis, 2011). The analysis of different MHs can

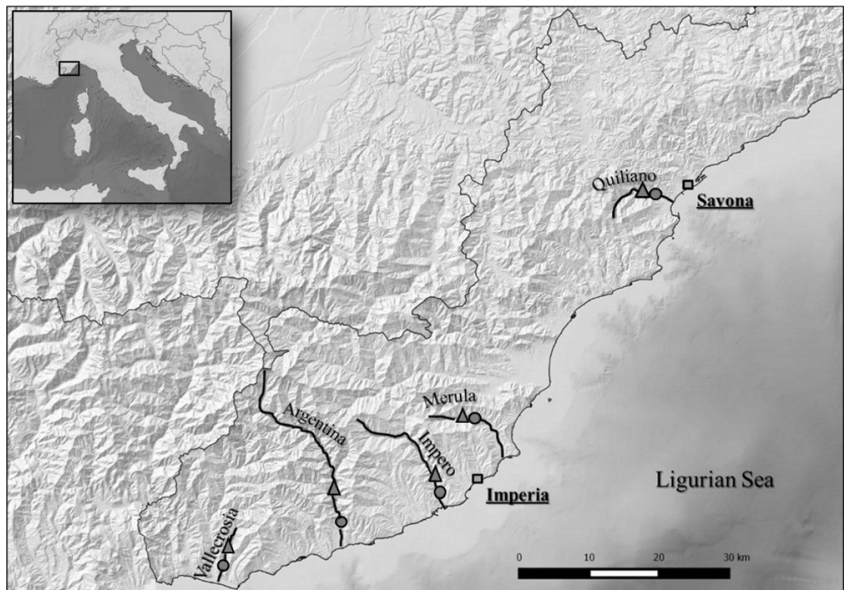

Fig. 1. Studied rivers and sampling sites locations.

also provide important information in terms of species autecology. Rare species that would be underestimated from the traditional sampling procedure can result significant for certain MHs, such as those characterized by slow or standing waters. Motile diatoms, for instance, are considered excellent indicators of anthropogenic impacts (Fore and Grafe, 2002). They are usually associated with siltation and are linked to depositional areas: the exclusion of these MHs from the traditional sampling implies the loss of important information in terms of water quality assessment.

In view of the great heterogeneity that characterizes Mediterranean streams, the aim of our research was to understand if the traditional sampling protocols are reliable for the ecological assessment of intermittent streams under maximal hydrological disturbance. Under comparable water quality conditions, we tested if a modified sampling strategy better accounts for the hydrological alterations. To this goal, we compared samples collected from several Mediterranean rivers following: (i) the traditional European standard method and (ii) a new approach aimed at collecting diatoms from the most diversified MHs present within the same stretch. Moreover, we tested and discussed if the most commonly diatom indices used in Italy resulting from this new sampling strategy provide additional information for the physical disturbance assessment. Finally, we investigated the response of functional metrics not included in the current diatom indices to hydrological disturbance. The results of our research will shed light on the response of benthic diatom communities to natural intermittency and will contribute to the interpretation of biotic responses to the unrestrained water scarcity events in non Mediterranean regions.

\section{Materials and methods}

\subsection{Site selection}

Samplings were performed in five streams flowing in the Ligurian Alps hydroecoregion (HER 122; NW Italy), namely Argentina, Impero, Merula, Quiliano and Vallecrosia (Fig. 1). In order to reduce the environmental variability among sites and focus only on physical disturbance induced by flow instability, we selected stretches with low nutrient inputs. To 
Table 1. Number of diatom samples analyzed in each river and month.

\begin{tabular}{llllllrr}
\hline Rivers & April & June & July & August & September & October & $N$ tot per site \\
\hline Argentina & 12 & 12 & 12 & 12 & 12 & - & 60 \\
Impero & 12 & 12 & 12 & 12 & 12 & 6 & 72 \\
Merula & 12 & 12 & 12 & 23 & 24 & 12 & 6 \\
Quiliano & 12 & 12 & 12 & 12 & 12 & - & 64 \\
Vallecrosia & 12 & 12 & 12 & 12 & 72 & 23 & 352 \\
$N$ tot per campaign & 60 & 60 & 60 & 71 & & \\
\hline
\end{tabular}

do this, we checked chemical data collected by the Environmental Protection Agency of Liguria (ARPAL) during the last ordinary surveys. For each river, we selected an upstream sampling site, generally characterized by permanent flow, and a downstream site with intermittent regime during the hot season. We then conducted a first sampling campaign in April 2014 in order to evaluate the flora colonizing the different stretches under optimal flow conditions. We then conducted four sampling campaigns along the whole hot season (June, July, late August, late September). Additional campaigns were carried out in those rivers particularly rich and interesting in terms of intermittency and $\mathrm{MH}$ peculiarity (Tab. 1). In particular, extra surveys were conducted in the Merula (in August, September and October) since it resulted one of the most interesting river in terms of diatom flora and because of its strong intermittency. One additional survey was carried out during October only in the downstream sites of the Impero and the Quiliano.

In each sampling site we chose six sampling plots: 1 transect (T), selected according to the standard diatom sampling procedure, and $5 \mathrm{MHs}$. MHs were chosen in order to represent the maximal environmental variability occurring within the site, in terms of flow velocity, depth, substrate composition, shadow, connection to the main flow and presence of macrophytes. When present, isolated pools were considered as a priority habitat to be sampled during the $\mathrm{MH}$ selection. In each $\mathrm{MH}$, we chose one single cobble at the centre of an ideal $40-\mathrm{cm}$ buffer. Water velocity and depth were measured exactly on the cobble surface (see Sect. 2.2 for further details), while additional information concerning substrate composition, shadow and macrophyte coverage was visually detected within the buffer area.

\subsection{Environmental parameters}

In each transect $(\mathrm{T})$, physical-chemical parameters (water dissolved oxygen, $\mathrm{pH}$, temperature, conductivity, total suspended solids, soluble reactive phosphorous (SRP) and nitrates) were detected as described in Piano et al. (2016). In isolated pools, additional measures of the same parameters were collected (see Piano et al., 2016). Water velocity $(0.05 \mathrm{~m}$ from the bottom) was measured by means of a current meter (Mod RHCM Idromar): we performed 3 measures in each $\mathrm{T}$ section and 1 in each MH. At the same time and in the same plots we measured water depth. In each $\mathrm{MH}$, epilithic diatom chlorophyll $a$ was detected by means of the Benthotorch , a portable fluorimetric probe. After choosing the cobble representative for each of the selected $\mathrm{MH}$, we performed three measures of benthic diatom chlorophyll $a$ in three different portions of its surface. From these three measures, we extracted the median value.

\subsection{Diatom collection, treatment and identification}

For each sampling site, we collected 6 benthic diatom samples, keeping them separated for the subsequent community analyses and diatom indices calculation. The first one was collected following the standard procedure $(\mathrm{T})$ consisting in brushing 5 different cobbles chosen in the main flow, under stable conditions (European Committee for Standardization, 2003). Further, 5 diatom samples were collected from 5 different MHs, by brushing one single cobble from each of them. We chose to sample only one single cobble in each $\mathrm{MH}$ because we wanted to measure, in the best possible way, the existing relationship between diatom community and the surrounding environment. In each survey, we thus collected 12 samples per river: 6 in the upstream stretch with permanent flow all over the year, and 6 in the downstream site characterized by intermittency. In total, we collected 354 diatom samples (Tab. 1). Diatom communities were analyzed only in those samples showing median values of diatom chlorophyll $a>0.05 \mathrm{mg} \mathrm{L}^{-1}$, i.e. 352 samples out of 354 .

Diatom samples were preserved in ethanol immediately after sampling. Following the standard methods, samples were treated in laboratory by using hydrogen peroxide $(30 \%)$ and $\mathrm{HCl}(1 \mathrm{~N})$ in order to obtain clean frustules suspension. Permanent slides were mounted with Naprax ${ }^{\circledR}$ and observed under light microscope (Leitz Diaplan) with a $100 \times$ oil immersion objective. Diatom identification was based on several diatom floras and monographies, as well as on recent taxonomic papers (Krammer and Lange-Bertalot, 1986, 1988, 1991a, b; Lange-Bertalot and Metzeltin, 1996; Krammer, 1997a, b; Reichardt, 1999; Lange-Bertalot, 2001; Krammer, 2002, 2003; Werum and Lange-Bertalot, 2004; Blanco et al., 2010; Hofmann et al., 2011; Bey and Ector, 2013; Falasco et al., 2013; Ector et al., 2015).

For each sample, at least 400 valves were identified at species level as recommended in the standard guidelines for the diatom indices applications (European Committee for standardization, 2004). Diatom species were classified into ecological guilds according to Rimet and Bouchez (2012). Inventories were inserted in the software OMNIDIA 5.3, with 2015 database, in order to calculate diatom indices. In this research, we focused on the three indices used in Italy for the ecological classification of the watercourses (DM 260/2010): Specific Polluosensitivity Index (IPS; CEMAGREF, 1982), 
Table 2. Metrics used to assess hydrological stability. Score of 5, 3, 1 were assigned to each metric according to Karr (1981). Note that, by definition, transects were always "connected" to the main flow. The metric DEPTH was scored in a different way according to the sample type.

\begin{tabular}{llll}
\hline & & \multicolumn{2}{c}{ Metric score } \\
\cline { 2 - 4 } Metrics & 5 & 3 & 1 \\
\hline Month & April & June, July, October & August, September \\
Connection & Connected & Semi-connected & Isolated \\
Water velocity $\left(\mathrm{m} \mathrm{s}^{-1}\right)$ & $>0.20$ & $\leq 0.20$ and $>0$ & 0 \\
Depth $(\mathrm{m})$ & & $\leq 0.45$ and $>0.10$ & $\leq 0.10$ \\
Transect & $>0.45$ & $>0.45$ & $\leq 0.10$ \\
Microhabitat & $\leq 0.45$ and $>0.10$ & & \\
\hline
\end{tabular}

Table 3. Indices classification and relative thresholds. HS (Hydrological Stability); IPS (Specific Polluosensitivity Index), TI (Trophic Index); ICMi (Intercalibration Common Metric Index). M1 = Mediterranean macrotypology; small streams, mean altitude; M4=Mediterranean macrotypology; mean dimension streams, mountain; M5 = Mediterranean macrotypology; intermittent streams.

\begin{tabular}{lllllll}
\hline & Quality & HS & IPS & TI & & ICMi \\
\cline { 4 - 7 } & & & & & M1-M4 & M5 \\
\hline I class & High & $16-20$ & $17-20$ & $1-1.5$ & $0.80-1$ & $0.88-1$ \\
II class & Good & $12-14$ & $13-16.9$ & $1.6-2.6$ & $0.61-0.79$ & $0.65-0.87$ \\
III class & Moderate-bad & $4-10$ & $0-12.9$ & $2.7-4$ & $0-0.60$ & 0.64 \\
\hline
\end{tabular}

Trophic Index (TI; Rott et al., 1999) and the Intercalibration Common Metric Index (ICMi; Mancini and Sollazzo, 2009). From our analyses, we set up 3 different biological databases including the diatom communities detected in the: (1) samples from all the transects (T); (2) samples from all the single $\mathrm{MH}$; (3) the sum of the 6 inventories for each sampling site ( $\mathrm{T}+\mathrm{MHs})$. Thus, starting from the communities within these three databases, we calculated diatom indices, through OMNIDIA 5.3.

\subsection{Hydrological stability (HS) classification}

On the basis of our dataset, we classified sampling sites in terms of HS. The aim of this classification was to group the samples we collected on the basis of the physical disturbance created by the water scarcity. HS cannot be considered as a general index for classifying rivers in terms of HS, since it is based on specific conditions referred to our dataset. We based our classification on the following four attributes: (i) sampling month (hereinafter MONTH), as a proxy of the effect of water reduction on benthic communities. The temporal and progressive meaning of this variable was related to the additive stress that water scarcity creates on the biological components; (ii) connection of the habitat with the main flow (hereinafter CONNECTION), as a proxy of fragmentation; (iii) water velocity (hereinafter VELOCITY) and (iv) depth (hereinafter DEPTH), as proxies of lentification. For each attribute, we assigned a score as reported in Table 2. Thresholds of the metric DEPTH represented the 25th and 90th percentiles of our data distribution respectively. DEPTH was scored in a different way according to the sample type: for transect, we evaluated that the highest the water depth, the highest the HS (please note that depth in the T was always $<0.50 \mathrm{~m}$ ). In MHs, we attributed an intermediate score to the highest depths because they were generally isolated pools with standing water where we observed an excessive growth of macrophytes, which prevented the light to reach the periphyton. The lowest DEPTH score was attributed to the shallowest plots due to the high evaporation rate. HS for each sampled plot was then calculated as the sum of the 4 metric scorings. The final HS values ranged from 4 to 20 , defining the lowest and the highest HS respectively.

Finally, each value of HS was assigned to one out of three quality classes. Thresholds of quality classes were determined based on our data distribution, in order to have equal numbers of observation for each class (Tab. 3). To obtain reliable comparisons with the three HS classes, we revised diatom indices classification to reduce them to three classes, grouping together similar responses (see thresholds in Tab. 3).

We daily monitored rainfalls through the website of the ARPAL, in order to register possible seasonal anomalies in the precipitation amounts. This website provides data from several precipitation detectors displaced on the Ligurian territory (http://93.62.155.214/ omirl/WEB/mappa_sensori.html?pa $\mathrm{ra}=$ rai). In particular, four stations were constantly monitored: "Albenga" for the Merula river, "Sanremo" for the Argentina and Vallecrosia rivers, "Imperia" for the Impero river, "Savona" for the Quiliano river. It should be also noted that the progressive water reduction in our sampling streams was also due to the uncontrolled water uptakes all along the watercourses. A map of the major authorized concessions for the water diversions for human use is shown at the official website of the Ligurian Region (http://geoportale.regione. liguria.it/geoviewer/pages/apps/ambienteinliguria/mappa.html? id=1641\&ambiente=I). 


\subsection{Statistical analyses}

After checking for normal distribution of variables via Shapiro-Wilk test, we applied a Two-way ANOVA to explore the trend of diatom indices according to the single metrics included in the HS (MONTH, CONNECTION, WATER VELOCITY and DEPTH) and to sampling methods ( $\mathrm{T} v s \mathrm{MH}$ ).

Then, we tested the reliability of the new sampling approach (the sum of the whole inventories deriving from $\mathrm{T}$ and $\mathrm{MHs}$, i.e. $\mathrm{T}+\mathrm{MH}$ ) in the detection of the hydrological disturbance. In other words, we tested if a more exhaustive sampling procedure better reflects hydrological disturbance than the traditional one. To check this, we applied paired $t$-test in order to assess possible differences among HS classes calculated from $\mathrm{T}$ and $\mathrm{T}+\mathrm{MH}$ data.

In order to check for the ability of diatom indices to classify sites on the basis of the hydrological disturbance, a pairwise concordance was measured, by calculating the percentage of sites classified by diatom indices in the same HS quality class. This measure was obtained for both $\mathrm{T}$ and $\mathrm{T}+\mathrm{MH}$ methods.

As a final step, we considered the response of functional metrics, namely diatom chlorophyll $a$ and ecological guilds, to hydrological disturbance. For chlorophyll $a$ concentration, we tested the response to HS classes by means of a Kruskal-Wallis test, followed by a post-hoc test with Bonferroni correction, in order to keep into account the non-normal distribution of the dependent variable. Differences in terms of relative abundances of diatom guilds among HS classes and sampling approach $(\mathrm{T} v s \mathrm{~T}+\mathrm{MH})$ were tested via two-way ANOVA. Moreover, two-way ANOSIM followed by SIMPER analysis was performed on the number of species belonging to the different ecological guilds in order to test differences among HS classes and sampling approach $(\mathrm{T}+\mathrm{MH})$. ANOSIM was performed with a Bray-Curtis distance measure and its significance was tested by 9999 permutations.

Statistical analyses were performed with the statistical software PAST 3.11 (Hammer et al., 2001).

\section{Results}

Chemical-physical parameters revealed a good water quality in all the studied sites (Tab. 4). The 5 investigated rivers were comparable in terms of organic load and anthropic impact. Nutrient concentrations were always low, in all the rivers and during the whole experiment: SRP were always contained within the highest quality class in all cases, and nitrates within the second class (Italian Water Legislation D. Leg. 152/2006 and successive ones). No important seasonal variations in nutrient concentrations were observed. Figure $2 \mathrm{a}$ and $b$ shows the results of the cumulative monthly precipitations and maximum air temperatures detected in 2014. An increase of the daily precipitations registered in summer is also shown (Fig. 2c-f). From June to the end of September, the precipitations were sporadic and rarely exceeded $10 \mathrm{~mm}$ of rain. At the beginning of October, rain increased in frequency and intensity in all the studied rivers showing peaks in Merula and Quiliano streams.

\subsection{Diatom indices and sampling methods}

Diatom indices denoted a good/high status in all the sites according to water quality. It should be noted that more than a half of ICMi values exceeded 1, which means that the observed values greatly overcame reference values defined by the national standards (DM 260/2010). TI was slightly stricter than the other two indices, since it classified some samples as eutrophic. We initially focused on the differences between the single attributes composing the HS and diatom indices (Tabs. 5 and 6).

Considering the metric MONTH, IPS worsened during the hot season and this pattern was observed in samples collected from both Ts and MHs, even though the lowest values were reached in the $\mathrm{T}$ samples (Tab. 5). On the contrary, the lowest values of TI were calculated in samples deriving from MHs, collected in August and September. The same pattern was observed for $\mathrm{T}$ samples, but the difference among months was slighter. The pattern of ICMi was different from the previous ones: both in $\mathrm{T}$ and $\mathrm{MH}$ samples, ICMi was higher for intermediate flows (June, July and October), while the lowest values were observed in April, August and September. Our observations were partly confirmed by the Two-way ANOVA, since a significant difference between diatom indices belonging to the three MONTH classes was observed (Tab. 6).

When checking for an effect of CONNECTION, no differences were observed between IPS values calculated on samples derived from $\mathrm{Ts}$, where stretches were always connected to the main channel, and MHs, including connected, semi-connected and isolated areas (Tab. 5). Not even TI was able to measure a disturbance in the isolated MHs. Surprisingly, ICMi values were even higher in the isolated pools than in the connected or semi-isolated sites. It was not possible to perform a Two-way ANOVA on this set of data because of the lack of semi-connected and isolated areas within the $\mathrm{T}$ approach. The ANOVA conducted on $\mathrm{MH}$ data did not reveal differences among HS classes and diatom indices (Tab. 6).

The pattern of diatom indices with respect to water flow VELOCITY was similar: all the indices denoted a worsen when water flow in Ts was zero. On the contrary, diatom indices derived from $\mathrm{MH}$ sampling did not reveal differences among VELOCITY classes. Two-way ANOVA statistically confirmed our observations only for IPS (Tab. 6): there was a significant difference between IPS calculated from different VELOCITY classes. Regarding water DEPTH, there was no clear pattern concerning diatom indices. IPS did not register any difference among classes of DEPTH (Tab. 6). Concerning TI, there seems to be a tendency to increase its values in deepest areas of the transect. Concerning ICMi, there was an opposite trend between $\mathrm{T}$ and $\mathrm{MH}$ samples: ICMi decreased in deepest sections of the transect and increased in shallow pools.

\subsection{Comparison between HS and diatom indices}

Based on HS, as defined in Section 2, $28 \%$ of the plots (both Ts and MHs) were classified with low hydrological disturbance $(20<\mathrm{HS}<16), 47 \%$ showed intermediate 
E. Falasco et al. : Knowl. Manag. Aquat. Ecosyst. 2016, 417, 38

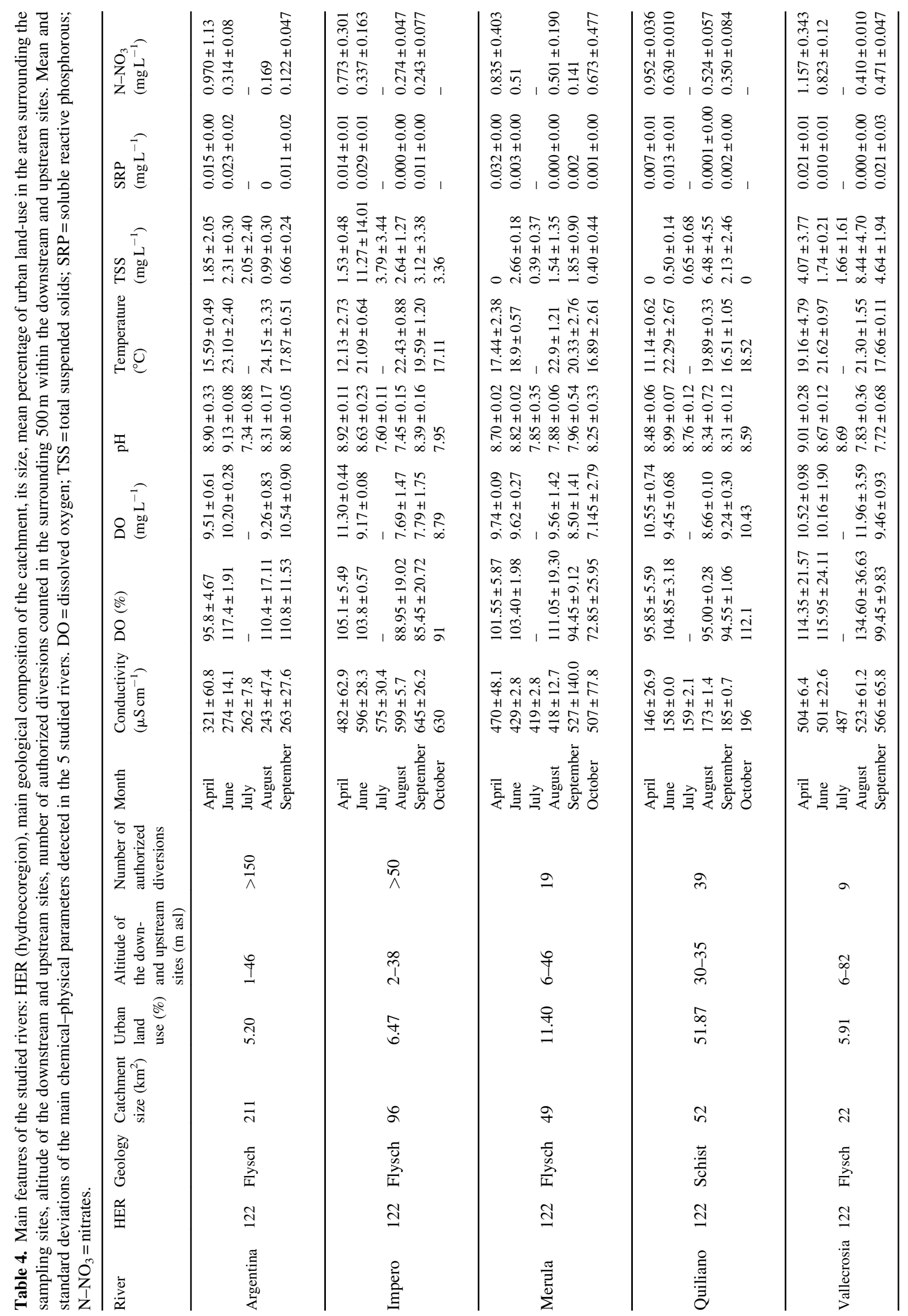




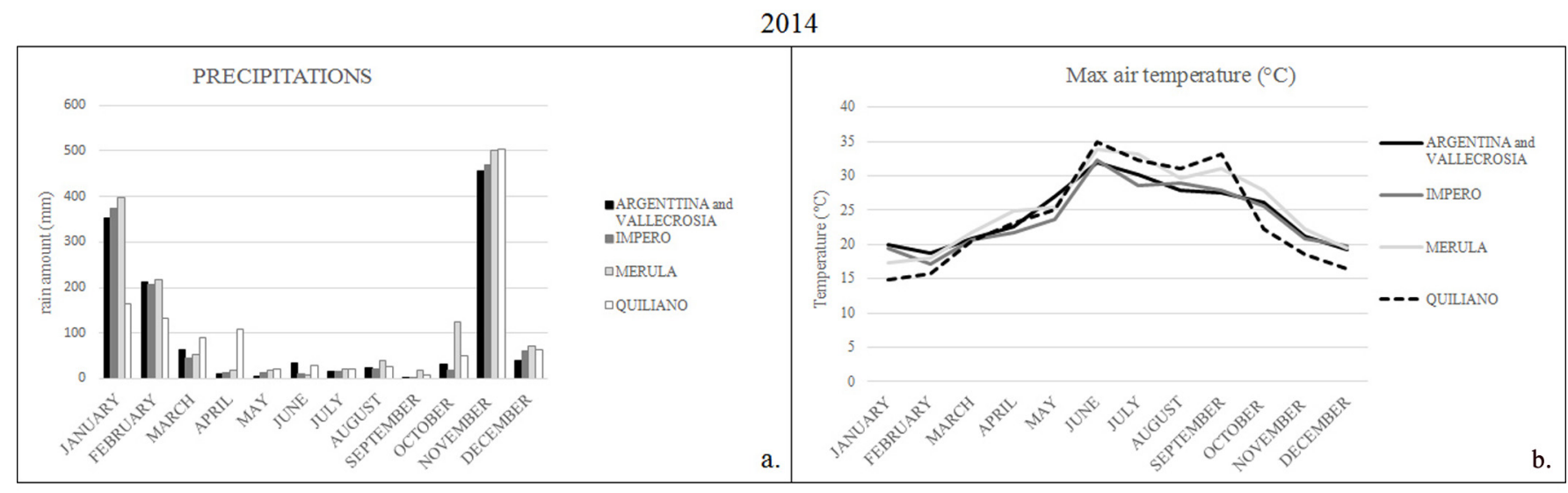

\section{SUMMER PRECIPITATIONS}

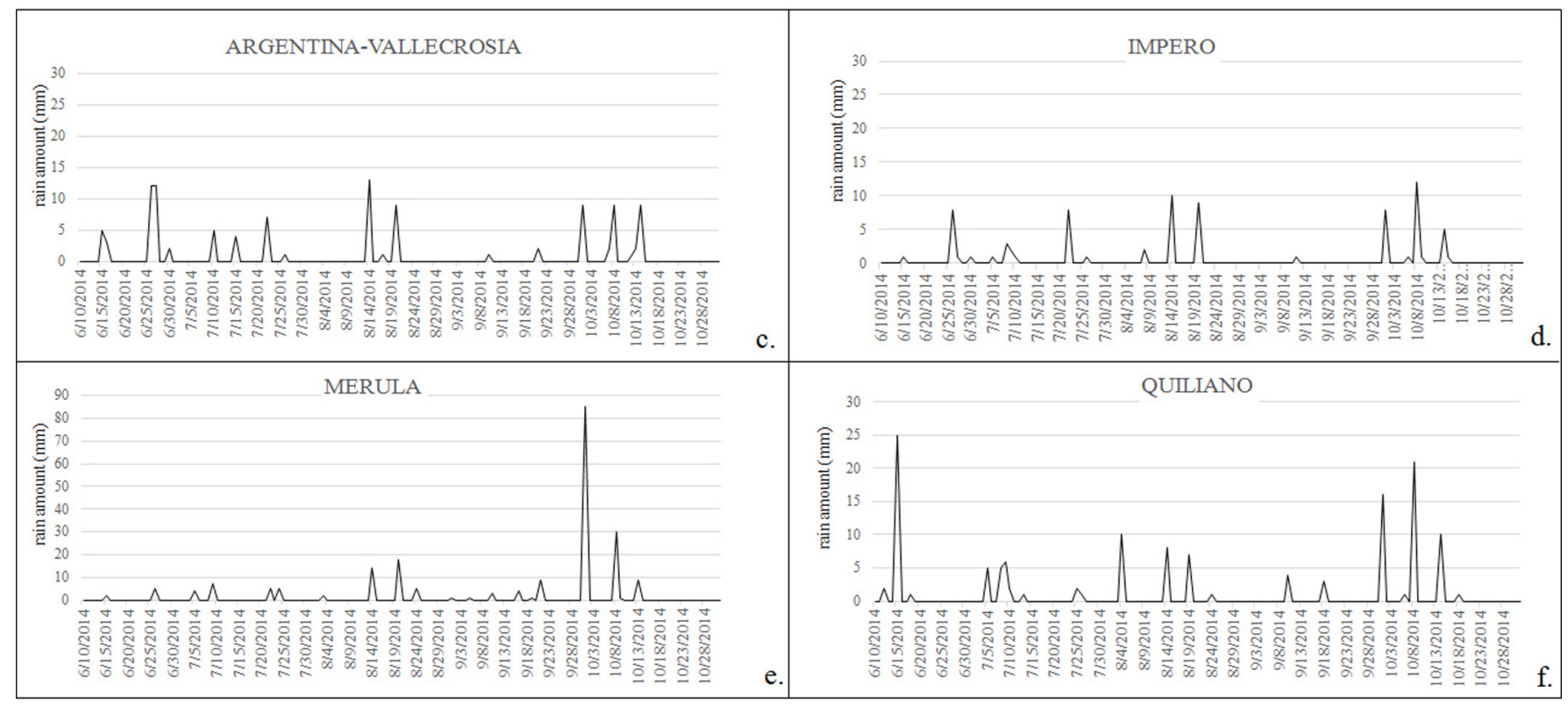

Fig. 2. (a) Monthly cumulative precipitations and (b) maximum air temperature detected in all the monitored rivers in 2014. (c-f) Daily precipitations detected in all the monitored rivers from June to the end of October.

conditions $(14<\mathrm{HS}<12)$, while the resting $25 \%$ were characterized by high hydrological disturbance $(10<\mathrm{HS}$ $<4)$. Sampling method proved to be important for the HS definition. Indeed, the result of the paired $t$-test highlighted a significant difference between HS calculated from samples obtained from $\mathrm{Ts}$ and those obtained from $\mathrm{T}+\mathrm{MH}(t=2.15$; $P=0.048$; Fig. 3). Indeed, to check if diatom indices are able to capture hydrological disturbance, we compared sample classification based on HS and diatom indices calculated from samples deriving from the traditional sampling approach (T) and those deriving from the experimental approach (the sum of the 6 diatom communities collected in each sampling site: $\mathrm{T}+\mathrm{MH}$ ).

The percentage of sites for which there was a correspondence between HS classes and diatom indices classes, calculated both from $\mathrm{T}$ and $\mathrm{T}+\mathrm{MH}$ approaches, is shown in Table 7. The percentage of concordance between HS classes and diatom indices was generally low to indicate that part of the information obtained from the HS calculation was lost when diatom indices were computed. Moreover, the concordance was even lower when indices were calculated with the $\mathrm{T}+\mathrm{MH}$ approach. Since the $\mathrm{T}+\mathrm{MH}$ approach proved to include a higher percentage of hydrological disturbance than $\mathrm{T}$, the lower concordance between HS and diatom indices measured with this method further confirmed the poor ability of diatom indices in taking into account the hydrological alteration. In particular, by plotting HS and the diatom indices, we can find the lowest correspondence when the hydrological disturbance was maximum, i.e. low HS values and good/high diatom indices (Fig. 4).

\subsection{Functional metrics}

The results of chlorophyll $a$ detected in the MHs and the percentages of the ecological guilds in $\mathrm{T}$ and $\mathrm{T}+\mathrm{MH}$ are displayed in Table 8. Results of the Kruskal-Wallis test showed significant differences in terms of benthic diatom 
Table 5. Mean and standard deviations of diatom indices (IPS, TI and ICMi) calculated for the single metric scorings of the HS, through different sampling methods $(\mathrm{T}=$ transect and $\mathrm{MH}=$ microhabitat). IPS (Specific Polluosensitivity Index); TI (Trophic Index); ICMi (Intercalibration Common Metric Index).

\begin{tabular}{|c|c|c|c|c|c|c|c|c|c|c|}
\hline \multirow[b]{2}{*}{ Metric } & \multirow[b]{2}{*}{$\begin{array}{l}\text { Sampling } \\
\text { method }\end{array}$} & \multicolumn{3}{|c|}{ Metric score: 5} & \multicolumn{3}{|c|}{ Metric score: 3} & \multicolumn{3}{|c|}{ Metric score: 1} \\
\hline & & IPS & TI & ICMi & IPS & TI & ICMi & IPS & TI & ICMi \\
\hline \multirow{2}{*}{ Month } & $\mathrm{T}$ & $17.6 \pm 1.36$ & $1.70 \pm 0.41$ & $1.04 \pm 0.15$ & $17.2 \pm 1.23$ & $1.77 \pm 0.37$ & $1.03 \pm 0.13$ & $16.3 \pm 1.79$ & $1.86 \pm 0.46$ & $0.99 \pm 0.17$ \\
\hline & MH & $17.1 \pm 1.52$ & $1.77 \pm 0.46$ & $1.01 \pm 0.16$ & $16.9 \pm 1.63$ & $1.78 \pm 0.47$ & $1.02 \pm 0.17$ & $16.1 \pm 2.25$ & $1.91 \pm 0.50$ & $0.97 \pm 0.19$ \\
\hline \multirow{2}{*}{ Connection } & $\mathrm{T}$ & $16.9 \pm 1.56$ & $1.80 \pm 0.41$ & $1.01 \pm 0.15$ & - & - & - & - & - & - \\
\hline & $\mathrm{MH}$ & $16.7 \pm 1.87$ & $1.83 \pm 0.47$ & $0.99 \pm 0.17$ & $16.6 \pm 1.63$ & $1.88 \pm 0.49$ & $1.00 \pm 0.16$ & $16.2 \pm 2.37$ & $1.78 \pm 0.53$ & $1.03 \pm 0.20$ \\
\hline \multirow{2}{*}{ Velocity } & $\mathrm{T}$ & $16.8 \pm 1.59$ & $1.78 \pm 0.42$ & $1.01 \pm 0.16$ & $17.1 \pm 1.57$ & $1.78 \pm 0.41$ & $1.02 \pm 0.15$ & $16.6 \pm 1.60$ & $2.10 \pm 0.28$ & $0.97 \pm 0.12$ \\
\hline & $\mathrm{MH}$ & $16.9 \pm 1.64$ & $1.82 \pm 0.43$ & $0.99 \pm 0.17$ & $17.1 \pm 1.53$ & $1.79 \pm 0.41$ & $1.03 \pm 0.15$ & $16.4 \pm 2.09$ & $1.84 \pm 0.51$ & $0.99 \pm 0.18$ \\
\hline \multirow[b]{2}{*}{ Depth } & $\mathrm{T}$ & $17.3 \pm 1.68$ & $1.99 \pm 0.30$ & $1.02 \pm 0.13$ & $16.9 \pm 1.67$ & $1.79 \pm 0.45$ & $1.00 \pm 0.16$ & $16.9 \pm 1.43$ & $1.78 \pm 0.36$ & $1.02 \pm 0.15$ \\
\hline & MH & $17.6 \pm 1.99$ & $1.86 \pm 0.49$ & $0.99 \pm 0.18$ & $17.0 \pm 1.93$ & $1.61 \pm 0.42$ & $1.05 \pm 0.17$ & $16.7 \pm 1.72$ & $1.86 \pm 0.48$ & $1.00 \pm 0.17$ \\
\hline
\end{tabular}

Table 6. Results of the two-way ANOVA applied on the diatom indices to evaluate differences among sampling methods (T vs MH) and HS attribute classes. Significant values are highlighted in bold.IPS (Specific Polluosensitivity Index); TI (Trophic Index); ICMi (Intercalibration Common Metric Index); HS (Hydrological Stability); T = traditional approach; MH = microhabitat.

\begin{tabular}{|c|c|c|c|c|c|c|c|c|c|}
\hline & \multirow[b]{3}{*}{ Variable } & \multicolumn{8}{|c|}{ HS attributes } \\
\hline & & \multicolumn{2}{|c|}{ Month } & \multicolumn{2}{|c|}{ Connection } & \multicolumn{2}{|c|}{ Velocity } & \multicolumn{2}{|c|}{ Depth } \\
\hline & & $F$ & $P$ & $F$ & $P$ & $F$ & $P$ & $F$ & $P$ \\
\hline \multirow{3}{*}{ IPS } & Treatment $(\mathrm{T} v s \mathrm{MH})$ & 1.13 & 0.288 & NA & NA & 1.1 & 0.296 & 1.08 & 0.3 \\
\hline & HS attribute class & 9.66 & $<\mathbf{0 . 0 0 1}$ & 1.09 & 0.299 & 4.05 & 0.018 & 0.98 & 0.377 \\
\hline & Interaction & 0.06 & 0.940 & NA & $\mathrm{NA}$ & 0.71 & 0.491 & 0.61 & 0.546 \\
\hline \multirow{3}{*}{ TI } & Treatment ( $\mathrm{T} v s \mathrm{MH})$ & 0.23 & 0.628 & NA & NA & 0.23 & 0.631 & 0.24 & 0.628 \\
\hline & HS attribute class & 3.18 & 0.043 & 0.23 & 0.630 & 0.43 & 0.65 & 2.71 & 0.068 \\
\hline & Interaction & 0.06 & 0.942 & NA & NA & 0.6 & 0.548 & 1.94 & 0.146 \\
\hline \multirow{3}{*}{ ICMi } & Treatment $(\mathrm{T} v s \mathrm{MH})$ & 0.47 & 0.491 & NA & NA & 0.47 & 0.494 & 0.47 & 0.494 \\
\hline & HS attribute class & 3.33 & 0.037 & 0.47 & 0.493 & 0.98 & 0.378 & 1.11 & 0.331 \\
\hline & Interaction & 0.04 & 0.964 & NA & NA & 0.32 & 0.724 & 0.99 & 0.371 \\
\hline
\end{tabular}

chlorophyll $a$ between HS classes $\left(\mathrm{Chi}^{2}=19.74 ; P<0.001\right)$. The post-hoc test, revealed that chlorophyll $a$ of samples belonging to the third HS class was significantly lower than the one observed in the other two classes $(P<0.014)$. After testing for normal distribution, we performed a two-way ANOVA to test if there was a significant difference between percentage of abundances of diatom guilds detected with the two sampling approaches ( $\mathrm{T}$ and $\mathrm{T}+\mathrm{MH}$ ), $\mathrm{HS}$ classes and their interaction (Tab. 9a). We observed a significant difference between sampling approaches $(\mathrm{T} v s \mathrm{~T}+\mathrm{MH})$ in terms of percentage of motile diatoms with higher values in $\mathrm{T}+\mathrm{MH}$ than $\mathrm{T}$. These results were confirmed by the two-way ANOSIM (Tab. 9b) and SIMPER analysis, that revealed a significant effect of the sampling approach on the number of motile species collected (Tab. 9c). Beside the motile guild, also the number of taxa belonging to high profile guild contributed in explaining this difference (Tab. 9c).

\section{Discussion}

In our study, we demonstrated that the spatial and temporal habitat heterogeneity and fragmentation that intermittency creates in the Mediterranean streams has to be taken into 


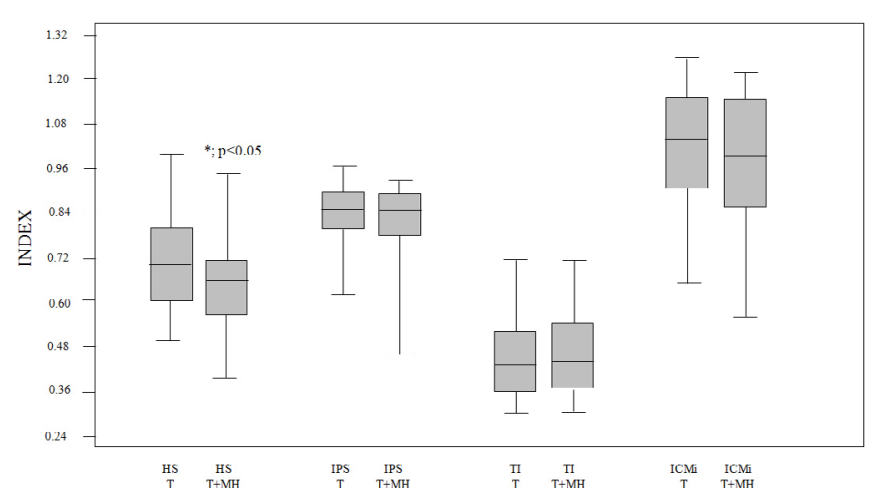

Fig. 3. Box-plots representing the variability of the indices (HS, IPS, TI and ICMi) calculated basing on two different approaches (T vs $\mathrm{T}+\mathrm{MH})$. In order to provide comparable results, all the indices were normalized from 0 to 1 . HS (Hydrological Stability); IPS (Specific Polluosensitivity Index); TI (Trophic Index); ICMi (Intercalibration Common Metric Index). $\mathrm{T}=$ traditional approach; $\mathrm{T}+\mathrm{MH}=$ experimental approach.

Table 7. The percentage of sites for which there was a correspondence between HS classes and diatom indices classes, calculated both from $\mathrm{T}$ and $\mathrm{T}+\mathrm{MH}$ approaches. HS (Hydrological Stability); IPS (Specific Polluosensitivity Index); TI (Trophic Index); ICMi (Intercalibration Common Metric Index). $\mathrm{T}=$ traditional approach; $\mathrm{T}+\mathrm{MH}=$ experimental approach.

\begin{tabular}{|c|c|c|c|c|c|c|}
\hline & \multicolumn{2}{|r|}{ IPS } & \multicolumn{2}{|r|}{ TI } & \multicolumn{2}{|c|}{ ICMi } \\
\hline & $\mathrm{T}$ & $\mathrm{T}+\mathrm{MH}$ & $\mathrm{T}$ & $\mathrm{T}+\mathrm{MH}$ & $\mathrm{T}$ & $\mathrm{T}+\mathrm{MH}$ \\
\hline HS & 47.5 & 39.0 & 50.8 & 49.1 & 45.8 & 28.8 \\
\hline
\end{tabular}

account during the assessment of the ecological status of the watercourses. Indeed, as already pointed out by Feio et al. (2014), environmental constraints characterizing Mediterranean rivers require appropriate methodologies for their water quality classification.

By comparing diatom indices and the single metrics related to the HS, we can deduce interesting observations, especially concerning the sampling month and the water flow velocity. Indeed, under comparable physical-chemical features, we noted a shift of the diatom communities toward tolerant taxa during the hottest months and mainly in the MHs. Even in nonMediterranean streams, taxonomic composition is heavily influenced by current velocity: diatom patches composition is highly related to assemblage location within a stretch (Passy, 2001). In this context, it is easy to understand how important is the investigation of MHs characterized by the most different water flows, especially in those streams where lentification process becomes a key factor during the warm season. Our results highlighted the importance to include in the sampling process also those areas where water velocity is null. Even though the collection of diatoms from depositional zones implicates the inclusion of dead frustules in the samples, it has been demonstrated that this does not affect the reliability of the diatom indices final score (Gillett et al., 2009; Barthès et al., 2014). The sampling of lentic MHs leads also to the inclusion of
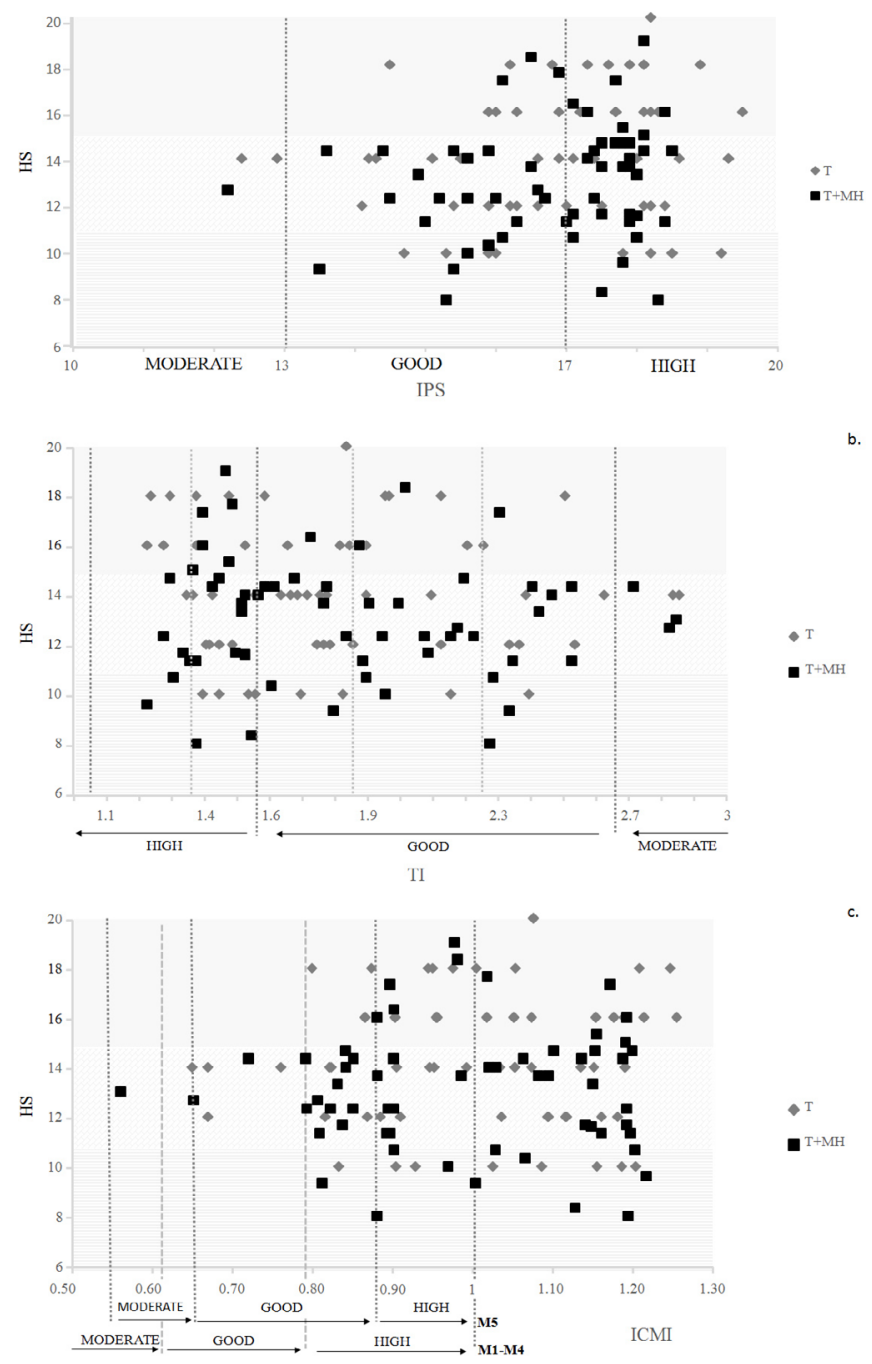

Fig. 4. Dispersion graphics between hydrological stability (HS) and diatom indices: (a) IPS; (b) TI and (c) ICMi. Sampling approach patterns $(\mathrm{T}=$ filled diamonds; $\mathrm{T}+\mathrm{MH}=$ filled squares $)$ are also displayed. Different backgrounds graphically represent HS quality classes. Vertical lines graphically represent diatom indices quality thresholds (see Tab. 3). $\mathrm{T}=$ traditional approach; $\mathrm{T}+\mathrm{MH}=$ experimental approach. M1 = Mediterranean macrotypology; small streams, mean altitude; M4 = Mediterranean macrotypology; mean dimension streams, mountain; M5 = Mediterranean macrotypology; intermittent streams.

an important component of the community that would be otherwise underestimated, i.e. the motile taxa, whose potentialities as physical disturbance indicators have been already recognized. Our observations match with the results obtained by Smucker and Vis (2010) who observed higher percentages of motile diatoms through a multihabitat sampling approach. Motile taxa are linked to depositional habitats and increased siltation: for this reason, they are also considered excellent indicators of anthropogenic impacts and show strong correlations with land use variables (Smucker and Vis, 2010). In Italy, several studies carried out in the Mediterranean hydroecoregions already pointed out the importance to detect the percentage of motile 
E. Falasco et al. : Knowl. Manag. Aquat. Ecosyst. 2016, 417, 38

Table 8. Mean and standard deviations, minimum and maximum values of the chlorophyll $a$ detected in the MHs under different HS classes. Mean and standard deviations, minimum and maximum values of the percentages of the diatom ecological guilds detected in the Ts and $\mathrm{T}+\mathrm{MH}$ under different HS classes. $\mathrm{T}=$ traditional approach; $\mathrm{T}+\mathrm{MH}=$ experimental approach; HS (Hydrological Stability).

\begin{tabular}{|c|c|c|c|c|c|c|}
\hline & & & & HS5 & HS3 & HS1 \\
\hline \multirow[t]{2}{*}{ Diatom chl $a$} & & & $\begin{array}{l}\text { Mean } \pm \text { st.dev } \\
(\min -\max )\end{array}$ & $\begin{array}{l}3.61 \pm 4.87 \\
(0.36-30.35)\end{array}$ & $\begin{array}{l}2.61 \pm 3.15 \\
(0.01-27.52)\end{array}$ & $\begin{array}{l}2.27 \pm 4.02 \\
(0-29.91)\end{array}$ \\
\hline & Low profile & $\begin{array}{l}\mathrm{T} \\
\mathrm{T}+\mathrm{MH}\end{array}$ & $\begin{array}{l}\text { Mean } \pm \text { st.dev } \\
(\text { min}- \text { max }) \\
\text { Mean } \pm \text { st.dev } \\
(\min -\max )\end{array}$ & $\begin{array}{l}77.22 \pm 11.31 \\
(50.00-92.00) \\
70.06 \pm 12.68 \\
(49.98-84.87)\end{array}$ & $\begin{array}{l}73.93 \pm 13.41 \\
(40.70-89.81) \\
73.74 \pm 11.49 \\
(44.47-90.40)\end{array}$ & $\begin{array}{l}77.29 \pm 16.11 \\
(50,34-98.35) \\
67.69 \pm 9.28 \\
(54.13-82.72)\end{array}$ \\
\hline \multirow[t]{2}{*}{ Ecological guilds } & High profile (+planktonic) & $\begin{array}{l}\mathrm{T} \\
\mathrm{T}+\mathrm{MH}\end{array}$ & $\begin{array}{l}\text { Mean } \pm \text { st.dev } \\
(\text { min}- \text { max }) \\
\text { Mean } \pm \text { st.dev } \\
(\text { min-max })\end{array}$ & $\begin{array}{l}12.92 \pm 7.88 \\
(3.08-30.02) \\
17.80 \pm 6.48 \\
(9.26-30.48)\end{array}$ & $\begin{array}{l}13.88 \pm 10.39 \\
(2.22-51.40) \\
12.27 \pm 6.95 \\
(3.43-26.28)\end{array}$ & $\begin{array}{l}14.66 \pm 12.94 \\
(1.65-36.56) \\
18.60 \pm 6.68 \\
(8.60-28.05)\end{array}$ \\
\hline & Motile & $\mathrm{T}+\mathrm{MH}$ & $\begin{array}{l}\text { Mean } \pm \text { st.dev } \\
(\text { min-max }) \\
\text { Mean } \pm \text { st.dev } \\
(\min -\max )\end{array}$ & $\begin{array}{l}9.85 \pm 9.86 \\
(1.93-46.92) \\
12.06 \pm 9.53 \\
(4.08-29.99)\end{array}$ & $\begin{array}{l}12.18 \pm 8.97 \\
(1.46-35.18) \\
13.98 \pm 9.00 \\
(2.19-50.52)\end{array}$ & $\begin{array}{l}8.05 \pm 6.22 \\
(0-17.27) \\
13.71 \pm 5.96 \\
(5.52-20.55)\end{array}$ \\
\hline
\end{tabular}

Table 9. a. Results of the two-way ANOVA applied on the relative abundance of ecological guilds to test differences among sampling approach (T $v s \mathrm{~T}+\mathrm{MH})$ and HS classes. b. Results of the two-way ANOSIM applied on the number of species belonging to different ecological guilds to test differences among sampling approach $(\mathrm{T} v s \mathrm{~T}+\mathrm{MH})$ and HS classes; $\mathrm{c}$. Results of the SIMPER analysis reporting the contribution of each ecological guilds. Groups are ordered based on their contribution to dissimilarity. Av. Dissim = average dissimilarity; Contrib. \%= contribution of each group to dissimilarity; Cumulative $\%=$ cumulative contribution of each group to dissimilarity; Mean $\mathrm{T}=$ mean abundance of each group in T; Mean $\mathrm{MH}+\mathrm{T}=$ mean abundance of each group in $\mathrm{MH}+\mathrm{T} . \mathrm{T}=$ traditional approach; $\mathrm{MH}=$ sampling in microhabitats; $\mathrm{T}+\mathrm{MH}=$ experimental approach .

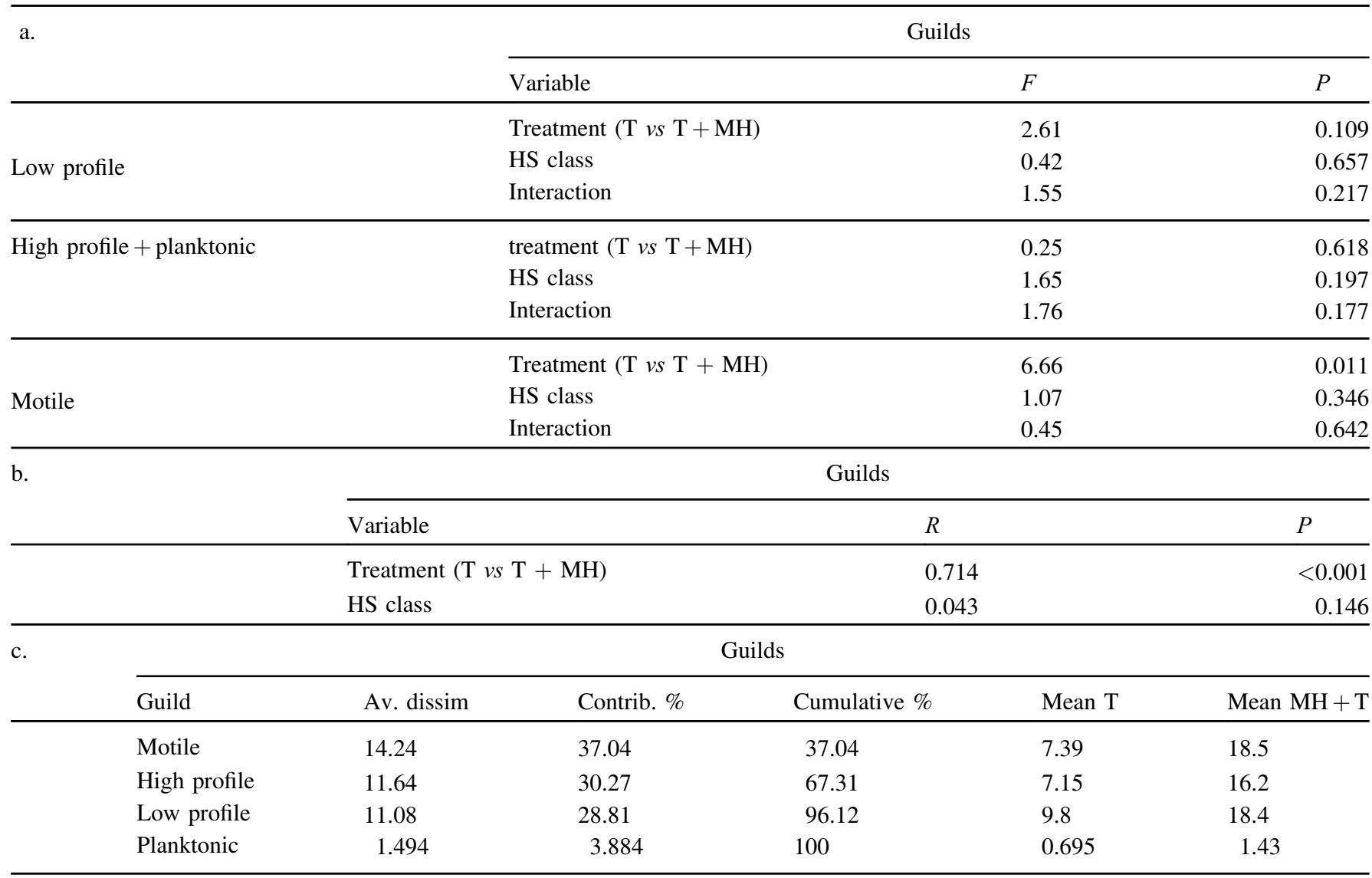


taxa to assess the disturbance caused by seasonal flow variations (Battegazzore et al., 2003; Battegazzore and Gastaldi, 2007; De Filippis et al., 2007; Finocchiaro et al., 2009; Gallo et al., 2013; Lai et al., 2014, 2016).

As far as the diatom indices have been conceived, the autecology of the taxa and the indicator species values for indices calculation are focused on the response to organic load and nutrient concentrations. Even though diatoms respond to the hydrological disturbance (Romaní et al., 2012; Barthès et al., 2014), its evaluation through community analysis still represents a challenge. In our study, functional metrics, such as chlorophyll $a$, resulted more reliable than diatom indices in the drought impact assessment, as already confirmed in previous studies (Ylla et al., 2010; Piano et al., 2016). Therefore, it could be advantageous to create a multimetric index that takes into account several functional metrics responding to hydrological disturbance.

The inclusion of different MHs during the sampling procedure does not require significant efforts and it is not time consuming, but several advantages can potentially arise from that. Indeed, beside better classifying intermittent streams, multi-habitat sampling presents also important implications in documenting species distribution and autecology. In heterogeneous streams, MHs potentially host rare and under-dispersed diatom species, which present higher risks for regional extinction and are largely underestimated through the sole traditional sampling approach (Smucker and Vis, 2011). Indeed, for biodiversity assessment purposes, samplings from different MHs are more advisable (Jüttner et al., 1996).

Our study means to be a starting point for the assessment of the hydrological disturbance in naturally and recently intermittent streams, and can provide useful food for thought during the monitoring of the major works affecting the natural river hydromorphology.

Acknowledgements. We would like to thank Marco Bodon and Anna Risso of ARPAL for providing useful data on Ligurian rivers and for their valuable help in scheduling the work. We also thank Sabrina Mossino, Marta Franchino, Alberto Doretto, Giacomo Bozzolino, Leonardo Manzari and Irene Conenna for their help in the fieldwork and in the laboratory analyses. This work is part of the research fellowship won by Dr. Elisa Falasco in 2014 "Diatom communities and droughts in Mediterranean rivers", cofounded by the University of Turin and by the Local Research Grant 60\% 2014 assigned to Francesca Bona.

\section{References}

Acuña V, Casellas M, Corcoll N, Timoner X, Sabater S. 2015. Increasing duration of flow intermittency in temporary waterways promotes heterotrophy. Freshwater Biol 60: 1810-1823.

Barceló D, Sabater S. 2010. Water quality and assessment under scarcity: prospects and challenges in Mediterranean watersheds. $J$ Hydrol 383: 1-4.

Barthès A, Leflaive J, Coulon S, Peres F, Rols JL, Ten-Hage L. 2014. Impact of drought on diatom communities and the consequences for the use of diatom index values in the River Maureillas (Pyrénées-Orientales, France). River Res Appl 31: 993-1002.
Battegazzore M, Gastaldi E. 2007. Diatomee di corsi d'acqua minori della Calabria e della Lucania (Sud Italia): inquadramento dell'indagine. Studi Trent Sci Nat: Acta Biol 83: 157-158.

Battegazzore M, Gallo L, Lucadamo L, Morisi A. 2003. Quality of the main watercourses in the Pollino National Park (Apennine Mts, S Italy) on the basis of the Diatom benthic communities. Studi Trent Sci Nat, Acta Biol 80: 89-93.

Bey MY, Ector L. 2013. Atlas des diatomées des cours d'eau de la region Rhône-Alpes. Tome 1-6. Direction régionale de l'Environnement, de l'Aménagegement et du Logement Rhône-Alpes, $1182 \mathrm{p}$.

Blanco S, Cejudo-Figueiras C, Álvarez-Blanco I, Bécares E, Hoffmann L, Ector L. 2010. Atlas de las diatomeas de la cuenca del Duero. Área de Publicaciones. León (Spain): Universidad de León, 386 p.

Boix D, García-Berthou E, Gascón S, et al. 2010. Response of community structure to sustained drought in Mediterranean rivers. J Hydrol 383: 135-146.

Bonada N, Rieradevall M, Prat N, Resh VH. 2006. Benthic macroinvertebrate assemblages and macrohabitat connectivity in Mediterranean-climate streams of northern California. $J \mathrm{~N} \mathrm{Am}$ Benthol Soc 25: 32-43.

CEMAGREF, 1982. Étude des méthodes biologiques d'appreciation quantitative de la qualité des eaux. Rapport Q. E. Lyon- A. F. Bassin Rhône- Mediterranée Corse. Lyon: Cemagref, 218 p.

De Filippis A, Gallo L, Lucadamo L, Mezzotero A, Battegazzore M. 2007. Qualità del principale corso d'acqua della Calabria (Fiume Crati), valutata mediante le comunità di diatomee. Studi Trent $S c i$ Nat, Acta Biol 83: 141-144.

Ector L, Wetzel CE, Novais MH, Guillard D. 2015. Atlas des diatomées des rivières des Pays de la Loire et de la Bretagne. Nantes: DREAL Pays de la Loire, 649 p.

Elias CL, Calapez AR, Almeida SFP, Feio MJ. 2015. From perennial to temporary streams: an extreme drought as a driving force of freshwater communities' traits. Mar Freshwater Res 66: 469-480.

European Committee for Standardization, 2003. Water quality guidance standard for the routine sampling and pretreatment of benthic diatoms from rivers. European standard EN 13946. Brussels: European Committee for Standardization, 14 p.

European Committee for standardization, 2004. Water quality guidance standard for the identification, enumeration and interpretation of benthic diatom samples from running waters. European Standard EN 14407. Brussels: European Committee for Standardization, $12 \mathrm{p}$.

Falasco E, Piano E, Bona F. 2013. Guida al riconoscimento e all'ecologia delle principali diatomee fluviali dell'Italia nord occidentale. Biol Ambientale 27: 1-292.

Feio MJ, Aguiar FC, Almeida SFP, et al. 2014. Least disturbed condition for European mediterranean rivers. Sci Total Environ 476-477: 745-756.

Fenoglio S, Bo T, Cucco M, Malacarne G. 2007. Response of benthic invertebrate assemblages to varying drought conditions in the Po river (NW Italy). Ital J Zool 74 (2): 191-201.

Fenoglio S, Bo T, Cucco M, Mercalli L, Malacarne G. 2010. Effects of global climate change on freshwater biota: a review with special emphasis on the Italian situation. Ital J Zool 77 (4): 374-383.

Finocchiaro M, Torrisi M, Ferlito A. 2009. Caratterizzazione delle comunità di diatomee bentoniche del bacino idrografico del fiume Simeto (Sicilia orientale) mediante applicazionedell'Indice Diatomico di Eutrofizzazione/Polluzione (EPI-D). Biol Ambientale 23: 53-66.

Fisher J, Dunbar MJ. 2007. Towards a representative periphytic diatom sample. Hydrol Earth Syst Sci 11: 399-407. 
Fore LS, Grafe C. 2002. Using diatoms to assess the biological condition of large rivers in Idaho (U.S.A.). Freshwater Biol 47: 2015-2037.

Gallo L, Battegazzore M, Corapi A, de Filippis A, Mezzotero A, Lucadamo L. 2013. Environmental analysis of a regulated Mediterranean stream based on epilithic diatom communities the Crati River case (southern Italy). Diatom Res 28: 143-156.

Gillett N, Pan Y, Parker C. 2009. Should only live diatoms be used in the bioassessment of small mountain streams? Hydrobiologia 620: 135-147.

Gordon ND, McMahon TA, Finlayson BL. 1992. Stream hydrology: an introduction for ecologists, 1st ed. West Sussex PO19 8SQ, England: Prentice-Hall, Wiley \& Sons.

Hammer Ø, Harper DAT, Ryan PD. 2001. PAST: paleontological statistics software package for education and data analysis. Paleont Electr 4: 1-9.

Hofmann G, Werum M, Lange-Bertalot H. 2011. Diatomeen im Süßwasser-Benthos von Mitteleuropa. Königstein: Koeltz Scientific Books, $908 \mathrm{p}$.

Jüttner I, Rothfritz H, Ormerod SJ. 1996. Diatoms as indicators of river quality in the Nepalese Middle Hills with consideration of the effects of habitat-specific sampling. Freshwater Biol 36: 475-486.

Karr JR. 1981. Assessment of biotic integrity using fish communities. Fisheries 6: 21-27.

Kelly MG, Cazaubon A, Coring E, et al. 1998. Recommendations for the routine sampling of diatoms for water quality assessments in Europe. J Appl Phycol 10: 215-224.

Krammer K. 1997a. Die cymbelloiden Diatomeen. Teil 1. Allgemeines und Encyonema Part. Bibliotheca Diatomologica 36, 382 p.

Krammer K. 1997b. Die cymbelloiden Diatomeen. Teil 2. Encyonema part, Encyonopsis and Cymbellopsis. Bibliotheca Diatomologica 37, $469 \mathrm{p}$.

Krammer K. 2002. Cymbella. In: Lange-Bertalot H, ed. Diatoms of Europe. 3. Rugell: A.R.G. Gantner Verlag KG, 584 p.

Krammer K. 2003. Cymbopleura, Delicata, Navicymbula, Gomphocymbellopsis, Afrocymbella. In: Lange-Bertalot H, ed. Diatoms of Europe. 4. Rugell: ARG Gantner Verlag KG, 530 p.

Krammer K, Lange-Bertalot H. 1986. Bacillariophyceae Teil: Naviculaceae. 1. In: Ettl H, Gerloff J, Heynig H, Mollenhauer D, eds. Süsswasserflora von Mitteleuropa. 2. Stuttgart: Fischer Verlag, $876 \mathrm{p}$.

Krammer K, Lange-Bertalot H. 1988. Bacillariophyceae Teil: Bacillariaceae, Epithemiaceae, Surirellaceae. 2. In: Ettl H, Gerloff J, Heynig H, Mollenhauer D, eds. Süsswasserflora von Mitteleuropa. 2. Stuttgart: Fischer Verlag, 610 p.

Krammer K, Lange-Bertalot H. 1991a. Bacillariophyceae Teil: Centrales, Fragilariaceae, Eunotiaceae. 3. In: Ettl H, Gerloff J, Heynig H, Mollenhauer D, eds. Süsswasserflora von Mitteleuropa. 2. Stuttgart: Fischer Verlag, 598 p.

Krammer K, Lange-Bertalot H. 1991b. Bacillariophyceae Teil: Achnanthaceae. Kritische Erg.anzungen zu Navicula (Lineolatae) und Gomphonema. 4. In: Ettl H, Gerloff J, Heynig H, Mollenhauer D, eds. Süsswasserflora von Mitteleuropa. 2. Stuttgart: Fischer Verlag, $437 \mathrm{p}$.

Lai GG, Padedda BM, Virdis T, Sechi N, Lugliè A. 2014. Benthic diatoms as indicators of biological quality and physical disturbance in Mediterranean watercourses: a case study of the Rio Mannu di
Porto Torres basin, northwestern Sardinia, Italy. Diatom Res 29: $11-26$.

Lai GG, Padedda BM, Wetzel CE, Lugliè A, Sechi N, Ector L. 2016. Epilithic diatom assemblages and environmental quality of the $\mathrm{Su}$ Gologone karst spring (centraleastern Sardinia, Italy). Acta Bot Croat 75: 129-143.

Lake PS. 2000. Disturbance, patchiness, and diversity in streams. J N Am Benthol Soc 19: 573-592.

Lange-Bertalot H. 2001. Navicula sensu stricto, 10 Genera separated from Navicula sensu lato, Frustulia. In: Lange-Bertalot H, ed. Diatoms of Europe. 2. Rugell: A.R.G. Gantner Verlag K.G., 526 p.

Lange-Bertalot H, Metzeltin D. 1996. Indicators of oligotrophy. In: Lange-Bertalot H, ed. Iconographia Diatomologica. 2. Koenigstein: Koeltz, 390 p.

Mancini L, Sollazzo C. 2009. Metodo per la valutazione dello stato ecologico delle acque correnti: comunità diatomiche. Roma: Istituto Superiore della Sanità; 2009 (Rapporti ISTISAN 09/19).

Passy SI. 2001. Diatom ecological guilds display distinct and predictable behavior along nutrient and disturbance gradients in running waters. Aquat Bot 86: 171-178.

Piano E, Falasco E, Bona F. 2016. Mediterranean rivers: consequences of water scarcity on benthic algal chlorophyll $a$ content. J Limnol, doi:10.4081/jlimnol.2016.1503.

Reichardt E. 1999. Zur Revision der Gattung Gomphonema. Die Arten um G. affine/insigne, G. angustum/micropus, G. acuminatum sowie gomphonemoide Diatomeen aus dem Oberoligozän in Böhmen. In: Lange-Bertalot H, ed. Iconographia Diatomologica. 8. Rugell: A.R.G. Gantner Verlag K.G.

Rimet F, Bouchez A. 2012. Life-forms, cell-sizes and ecological guilds of diatoms in European rivers. Knowl Manag Aquat Ecosyst 406: 1-12.

Romaní AM, Amalfitano S, Artigas J, et al. 2012. Microbial biofilm structure and organic matter use in Mediterranean streams. Hydrobiologia 719: 43-58.

Rott E, Pfister P, van Dam H, et al. 1999. Indikationslisten für Aufwuchsalgen in Österreichischen Fliessgewässern, Teil 2: Trophieindikation und autökologische Anmerkungen Bundesministerium für Land- und Forstwirtschaf. Wien: Wasserwirtschaftskataster.

Smucker NJ, Vis ML. 2010. Using diatoms to assess human impacts on streams benefits from multiple-habitat sampling. Hydrobiologia 654: 93-109.

Smucker NJ, Vis ML. 2011. Contributions of habitat sampling and alkalinity to diatom diversity and distributional patterns in streams: implications for conservation. Biodivers Conserv 20: 643-661.

Tockner K, Stanford JA. 2002. Riverine floodplains: present state and future trends. Environ Conserv 29: 308-330.

Tornés E, Ruhí A. 2013. Flow intermittency decreases nestedness and specialization of diatom communities in Mediterranean rivers. Freshwater Biol 58: 2555-2566.

Werum M, Lange-Bertalot H. 2004. Diatoms in Springs from Central Europe and elsewhere under the influence of hydrogeology and anthropogenic impacts. In: Lange-Bertalot $\mathrm{H}$, ed. Iconographia Diatomologica 13. Koenigstein: Koeltz, 417 p.

Ylla I, Sanpera-Calbet I, Vázquez E, et al. 2010. Organic matter availability during pre- and post-drought periods in a Mediterranean stream. Hydrobiologia 657: 217-232.

Cite this article as: Falasco E, Piano E, Bona F. 2016. Suggestions for diatom-based monitoring in intermittent streams. Knowl. Manag. Aquat. Ecosyst., 417, 38. 